Vadim Kamenetsky · Nicole Métrich · Raffaello Cioni

\title{
Potassic primary melts of Vulsini (Roman Province): evidence from mineralogy and melt inclusions
}

Received: 31 July 1994/Accepted: 10 January 1995

\begin{abstract}
The origin and the relationships between the high potassic (HKS) and potassic (KS) suites of the Roman Comagmatic Province and the nature of their primary magmas have been intensively debated over the past 35 years. We have addressed these problems by a study of mineralogy (olivine $\mathrm{Fo}_{92-87}, \mathrm{Cr}$-spinel and diopside) and melt inclusions in olivine phenocrysts from a scoria sample of Montefiascone (Vulsini area). This rock is considered as one of the most primitive $(\mathrm{MgO}=13.5 \mathrm{wt} \%, \mathrm{NiO}=340 \mathrm{ppm} ; \mathrm{Cr}=1275 \mathrm{ppm})$ in the northern part of the Roman Comagmatic Province. The compositions of both the olivine and their melt inclusions are controlled by two main processes. In the case of the olivine $\mathrm{Fo}<90.5$, fractional crystallization (olivine + diopside + minor spinel) was the principal mechanism of the magma evolution. The olivine $\left(\mathrm{FO}_{92-90.5}\right)$ and the $\mathrm{Cr}$-spinel $(\mathrm{Cr} \#=$ 100. $\mathrm{Cr} /(\mathrm{Cr}+\mathrm{Al})=63-73)$ represent a near-primary liquidus assemblage and indicate the mantle origin of their parental magmas. The compositions of melt inclusions in these olivine phenocrysts correspond to those of poorly fractionated $\mathrm{H}_{2} \mathrm{O}$-rich $(\sim 1 \mathrm{wt} \%)$ primary melts $\left(\mathrm{MgO}=8.4-9.7 \mathrm{wt} \%, \mathrm{FeO}^{\text {total }}=6-7.5\right.$ wt $\%$ ). They evidence a wide compositional range (in $\mathrm{wt} \%: \mathrm{SiO}_{2}=46.5-50, \mathrm{~K}_{2} \mathrm{O}=5.3-2.8, \mathrm{P}_{2} \mathrm{O}_{5}=0.4-0.2$, $\mathrm{S}=0.26-0.12 ; \quad \mathrm{Cl}=0.05-0.03$, and $\mathrm{CaO} / \mathrm{Al}_{2} \mathrm{O}_{3}=$ $0.8-1.15$ ), with negative correlations between $\mathrm{SiO}_{2}$ and $\mathrm{K}_{2} \mathrm{O}, \mathrm{Al}_{2} \mathrm{O}_{3}$ and $\mathrm{CaO}$, as well as positive correlations between $\mathrm{K}_{2} \mathrm{O}$, and $\mathrm{P}_{2} \mathrm{O}_{5}, \mathrm{~S}, \mathrm{Cl}$, with nearly constant
\end{abstract}

V. Kamenetsky

Vernadsky Institute of Geochemistry, Moscow, Russia

N. Métrich $(\bowtie)$

Laboratoire Pierre Süe, G.S.T, CE-Saclay, F-91191 Gif/Yvette, France

R. Cioni

Dipartimento di Scienze della Terra, Via Santa Maria, I-56100 Pisa, Italy

Editorial responsibility: J. Touret ratios between these elements. These results are discussed in terms of segregation of various mantle-derived melts. The high and constant $\mathrm{Mg} \#$ $\left[100 . \mathrm{Mg} /\left(\mathrm{Mg}+\mathrm{Fe}^{2+}\right)\right] 73-75$ of studied melts and their variable $\mathrm{Si}, \mathrm{K}, \mathrm{P}, \mathrm{Ca}, \mathrm{Al}, \mathrm{S}$ contents could be explained by the melting of a refractory lithospheric mantle source, heterogeneously enriched in phlogopite and clinopyroxene (veined mantle source).

\section{Introduction}

The Quaternary potassic magmatism of the subduction-related Roman Comagmatic Province (RCP) was developed on the western branch of the Apennine chain. The northern part of this province offers a large compositional spectrum of volcanic rocks, from potassic (KS) and high potassic (HKS) series (Appleton 1972; Civetta et al. 1981; Peccerillo et al. 1984; Rogers et al. 1985; Giannetti and Ellam 1994) to strongly Si-undersaturated larnite-normative rocks (Kamafugite; Peccerillo et al. 1988). The HKS group $\left(\mathrm{K}_{2} \mathrm{O} / \mathrm{Na}_{2} \mathrm{O}>2\right.$; $\mathrm{K}_{2} \mathrm{O}>3 \mathrm{wt} \%$ ) includes Si-undersaturated rocks, from leucite basanite-tephritic leucitite to phonolite. The KS rocks $\left(\mathrm{K}_{2} \mathrm{O} / \mathrm{Na}_{2} \mathrm{O}=0.5-2, \mathrm{~K}_{2} \mathrm{O}=0.5-4 \mathrm{wt} \%\right)$ are represented by (nepheline/hypersthene/quartz normative) silica under- to over-saturated rocks, from olivine K-basalt to alkali trachyte (Serri et al. 1993). The HKS and KS series are closely associated in time and space (Appleton 1972; Civetta et al. 1981; Conticelli and Peccerillo 1992; Giannetti and Ellam 1994). Low-pressure crystal fractionation has generally been invoked to account for the evolution within a series (Appleton 1972; Civetta et al. 1981; Holm 1982; Holm et al. 1982; Peccerillo et al. 1984; Rogers et al. 1985), with possible additional processes such as crustal assimilation (Civetta et al. 1984; Conticelli et al. 1991), and magma mixing (Ferrara et al. 1986; Varekamp and Kalamarides 1989). 
The different HKS and KS series were formerly discussed as derived from distinct parental magmas (Appleton 1972; Civetta et al. 1981; Peccerillo et al. 1984) and debate about the nature of the primary magmas was extensively developed. The most primitive rocks of the RCP, and in particular, of the Vulsini area are considered by many authors as representative of near-primary melts (Holm et al. 1982; Varekamp 1979; Rogers et al. 1985; Varekamp and Kalamarides 1989; Coltorti et al. 1991; Conticelli and Peccerillo 1992), mainly based on such parameters as $\mathrm{Mg} \#, \mathrm{Ni}$ and $\mathrm{Cr}$ values, traditionally thought to be the reliable criteria of the primitiveness (e.g., Frey et al. 1978). However, this is not always a sufficient argument for proving the primary nature of the melt, especially taking into account the fact that highly potassic melts probably cannot be derived from the mantle of a typical peridotite composition (Foley 1992a). It is also well known that the magma storage and crystallization, within magma chambers identified in most of the volcanic systems, often prevent the emission of primary melts, as recently discussed in Marianelli et al. (1994). Melt inclusions trapped in early mineral phases may give an access to the compositions of the primary melts and record the mechanisms of melting and melt segregation (Sobolev and Shimizu 1993, 1994). We present a systematic study of melt inclusions in olivine phenocrysts from a leucitebasanite scoria sample from Montefiascone (Vulsini area). These olivines are the most primitive among those reported in HKS and KS rocks (Ghiara and Lirer 1977; Civetta et al. 1981; Peccerillo et al. 1984; Giannetti and Ellam 1994) and particularly in Vulsini lavas (Holm et al. 1982; Varekamp 1979; Varekamp and Kalamarides 1989; Coltorti et al. 1991; Conticelli and Peccerillo 1992).

Our data on the mineralogy and the melt inclusions demonstrate the broad compositional range of mantlederived melts. Their implications for the relationships between potassic and high potassic Si-undersaturated rocks from the northern part of the RCP are discussed.

\section{Geological setting and sample description}

The Vulsini volcanic district covers about $2280 \mathrm{~km}^{2}$ in the northernmost part of the Roman Comagmatic Province. It is composed of three main volcanic complexes (Bolsena, Montefiascone and Latera). The southern and south-eastern sectors of the district are mostly covered by the products of the Montefiascone Volcanic Complex. Several vents can be recognized in the area, related to some regional tectonic lineaments (NNW-SSE, WNW-ESE and EW; Coltorti et al. 1991) and to a polyphase calderic depression located in the SE corner of the Bolsena lake shoreline. A stratigraphy of the products related to the activity of Montefiascone has been proposed by different authors (Varekamp 1979; Marini and Nappi 1986; Cioni 1993). Coltorti et al. (1991) suggested that the Montefiascone activity was coeval with that of the Latera Complex, ranging from 278 and $145 \mathrm{ka}$, with some controversies on the exact temporal range spanned by the Montefiascone products (Cioni 1993).
The main phases of the Montefiascone volcanic activity may be summarized as follows:

1. Effusive and strombolian activities resulting in leucititic lava flows and scoria cones lined up on a WNW-ESE direction (Marini and Nappi 1986; Coltorti et al. 1991).

2. Successive explosive eruptions, caldera collapses, and emplacement of the Basal Montefiascone and Lava Drop ignimbrites (Marini and Nappi 1986), and of the Coste pyroclastic flow (Cioni 1993).

3. Effusive activity inside the Montefiascone depression and on its outer rims, deposition of lapilli beds related to strombolian activity of peri and intra-calderic scoria cones.

4. Phreatomagmatic eruption (La Berlina ignimbrite) and emplacement of the final scoria cone of Montefiascone and the associated lava flow.

Most of the Montefiascone rocks, defined as tephritic leucitites to leucititic tephrites (Coltorti et al. 1991), are characterized by leucite, clinopyroxene \pm olivine \pm plagioclase as phenocrysts. Magnesian olivine (Fo $>89$ ) only occurs in leucite basanites (LBSN) and some tephritic leucitites (Coltorti et al. 1991).

The investigated scoria (EBOL65) were collected from the final Montefiascone cone $\left(<0.1 \mathrm{~km}^{3}\right)$. It is defined as a leucite basanite, with high $\mathrm{MgO}(13.5 \mathrm{wt} \%)$ and $\mathrm{CaO}(13.8 \mathrm{wt} \%)$ contents (Table 2$)$, closely similar to the LBSN samples described by other authors (Rogers et al. 1985; Coltorti et al. 1991; Conticelli and Peccerillo 1992). The phenocrysts (up to $4 \mathrm{~mm}$ in size) are olivine, rare $\mathrm{Cr}$ spinel and clinopyroxene. Cr-spinel also occurs as inclusions in olivine. The groundmass, mainly glassy (Table 3) with quench crystals of clinopyroxene, rare olivine and spinel, reflects a rapid quenching.

\section{Minerals and melt inclusions}

\section{Mineralogy}

Olivine phenocrysts range in composition from $\mathrm{Fo}_{92}$ to $\mathrm{Fo}_{87.2}$ (Table 1). Some euhedral olivine crystals show concentric zones, particularly enriched in spinel inclusions, which outline the relict olivine interfaces. Profiles have indicated only limited compositional zoning (e.g., $\left.\mathrm{Fo}_{91.1}-\mathrm{FO}_{90}\right)$. The olivine $\left(\mathrm{FO}_{87.2}\right)$ is in equilibrium with the matrix glass. The most magnesian olivines $\left(\mathrm{FO}_{92-90.5}\right)$ show a steep increase in both $\mathrm{CaO}$ $(0.35-0.50 \mathrm{wt} \%)$, and $\mathrm{MnO}(0.1-0.2 \mathrm{wt} \%$; Fig. 1a, b) as $\mathrm{NiO}$ decreases from 0.35 to $0.2 \mathrm{wt} \%$ (Fig. 1c). For olivine $(\mathrm{Fo}<90.5)$, there is a clear change in the behavior of these elements (Fig. 1a, b, c). Spinel is Cr-spinel, with $\mathrm{Cr} \#[100 . \mathrm{Cr} /(\mathrm{Cr}+\mathrm{Al})]$ varying from 63 to 73 (Table 2; Fig. 2a). It is characterized by low $\mathrm{TiO}_{2}$ content between 0.4 and $0.6 \mathrm{wt} \%$, and its composition evolves with a significant decrease in the $\mathrm{Fe}^{2+} / \mathrm{Fe}^{3+}$ ratio $(2.5-1.5 \mathrm{wt} \%)$ as the olivine becomes Fe-richer (Fig. 2b). The clinopyroxene phenocrysts and microphenocrysts are poorly zoned diopsides $[\mathrm{Mg} \#=$ 100. $\mathrm{Mg} /\left(\mathrm{Mg}+\mathrm{Fe}^{2+}\right)=92-88$, Table 1, Fig. 3a), with $\mathrm{Al}_{2} \mathrm{O}_{3}$ positively correlated with $\mathrm{TiO}_{2}$ (Fig. 3b), and negatively with $\mathrm{SiO}_{2}$ (Fig. 3c). Early diopside $(\mathrm{Mg} \# 91.7)$ has been analyzed as inclusion in olivine $\left(\mathrm{Fo}_{89.7}\right)$. The clinopyroxene crystallization accounts for the slight decrease of the $\mathrm{CaO}$ content in olivine (Fo < 90.5; Fig. 1a). 
Table 1 Representative compositions of olivine, spinel and clinopyroxene. (1-7 host olivine phenocrysts and their spinel inclusions, $8-14$ olivine phenocrysts, 15 clinopyroxene inclusion in olivine (no 8); 16-20 clinopyroxene phenocrysts)

\begin{tabular}{|c|c|c|c|c|c|c|c|}
\hline Olivine & 1 & 2 & 3 & 4 & 5 & 6 & 7 \\
\hline $\mathrm{SiO}_{2}$ & 40.13 & 40.17 & 40.67 & 40.50 & 40.20 & 40.80 & 40.58 \\
\hline $\mathrm{FeO}$ & 7.98 & 8.09 & 8.18 & 8.24 & 8.44 & 8.87 & 9.15 \\
\hline $\mathrm{MnO}$ & 0.17 & 0.06 & 0.15 & 0.15 & 0.16 & 0.18 & 0.22 \\
\hline $\mathrm{MgO}$ & 50.00 & 50.14 & 49.89 & 49.40 & 50.03 & 50.26 & 49.86 \\
\hline $\mathrm{CaO}$ & 0.34 & 0.36 & 0.40 & 0.43 & 0.46 & 0.47 & 0.48 \\
\hline $\mathrm{NiO}$ & 0.27 & 0.32 & 0.25 & 0.18 & 0.22 & 0.21 & 0.19 \\
\hline Total & 98.89 & 99.14 & 99.55 & 98.89 & 99.51 & 100.78 & 100.47 \\
\hline Fo & 91.79 & 91.70 & 91.58 & 91.44 & 91.36 & 90.99 & 90.67 \\
\hline \multicolumn{8}{|l|}{ Spinel } \\
\hline $\mathrm{TiO}_{2}$ & 0.43 & 0.59 & 0.44 & 0.62 & 0.56 & 0.55 & 0.52 \\
\hline $\mathrm{Al}_{2} \widehat{\mathrm{O}}_{3}$ & 14.67 & 15.25 & 17.00 & 14.90 & 14.46 & 13.38 & 13.72 \\
\hline $\mathrm{Fe}_{2} \mathrm{O}_{3}$ & 5.10 & 5.46 & 6.65 & 7.06 & 7.55 & 8.84 & 9.49 \\
\hline $\mathrm{FeO}$ & 12.23 & 12.02 & 12.21 & 12.61 & 12.65 & 13.52 & 13.13 \\
\hline $\mathrm{MnO}$ & 0.17 & 0.21 & 0.22 & 0.25 & 0.22 & 0.22 & 0.24 \\
\hline $\mathrm{MgO}$ & 14.55 & 14.99 & 14.62 & 14.40 & 14.30 & 13.95 & 14.15 \\
\hline $\mathrm{Cr}_{2} \mathrm{O}_{3}$ & 52.75 & 52.23 & 48.13 & 50.20 & 50.30 & 51.24 & 50.20 \\
\hline Total & 99.89 & 100.75 & 99.27 & 100.03 & 100.05 & 101.70 & 101.46 \\
\hline $\mathrm{Mg}_{\#^{(\mathrm{a})}}$ & 67.97 & 68.98 & 68.10 & 67.06 & 66.84 & 64.78 & 65.76 \\
\hline $\mathrm{Cr} \#^{(b)}$ & 70.69 & 69.68 & 65.51 & 69.33 & 70.00 & 71.99 & 71.06 \\
\hline $\mathrm{Fe}^{2+} / \mathrm{Fe}^{3+}$ & 2.67 & 2.44 & 2.04 & 1.98 & 1.86 & 1.70 & 1.54 \\
\hline Olivine & 8 & 9 & 10 & 11 & 12 & 13 & 14 \\
\hline $\mathrm{SiO}_{2}$ & 41.03 & 40.42 & 40.45 & 39.54 & 40.21 & 40.12 & 40.42 \\
\hline $\mathrm{FeO}$ & 9.92 & 9.26 & 9.53 & 10.05 & 11.00 & 11.49 & 12.33 \\
\hline $\mathrm{MnO}$ & 0.22 & 0.20 & 0.19 & 0.22 & 0.18 & 0.20 & 0.26 \\
\hline $\mathrm{MgO}$ & 48.77 & 49.36 & 49.44 & 49.02 & 47.91 & 47.42 & 47.23 \\
\hline $\mathrm{CaO}$ & 0.48 & 0.51 & 0.48 & 0.45 & 0.50 & 0.46 & 0.45 \\
\hline $\mathrm{NiO}$ & 0.2 & 0.15 & 0.21 & 0.13 & 0.20 & 0.16 & 0.18 \\
\hline Total & 100.62 & 99.90 & 100.30 & 99.41 & 100.00 & 99.85 & 100.87 \\
\hline Fo & 89.76 & 90.48 & 90.24 & 89.68 & 88.59 & 88.04 & 87.23 \\
\hline Clinopyroxene & 15 & 16 & 17 & 18 & 19 & 20 & 21 \\
\hline $\mathrm{SiO}_{2}$ & 54.80 & 54.32 & 54.08 & 53.88 & 52.89 & 52.38 & 51.64 \\
\hline $\mathrm{TiO}_{2}^{2}$ & 0.17 & 0.21 & 0.26 & 0.29 & 0.40 & 0.46 & 0.57 \\
\hline $\mathrm{Al}_{2} \mathrm{O}_{3}$ & 1.47 & 1.93 & 1.99 & 2.50 & 2.80 & 3.91 & 4.80 \\
\hline $\mathrm{FeO}$ & 2.82 & 2.38 & 2.71 & 2.93 & 3.27 & 3.61 & 4.58 \\
\hline $\mathrm{MgO}$ & 17.39 & 17.78 & 17.56 & 17.18 & 16.82 & 16.13 & 15.27 \\
\hline $\mathrm{CaO}$ & 24.37 & 23.57 & 23.58 & 23.96 & 23.69 & 23.89 & 23.97 \\
\hline $\mathrm{Na}_{2} \mathrm{O}$ & 0.15 & 0.15 & 0.13 & 0.12 & 0.13 & 0.11 & 0.09 \\
\hline Total & 101.16 & 100.33 & 100.31 & 100.87 & 100.00 & 100.48 & 100.92 \\
\hline $\mathrm{Mg}^{(\mathrm{a})}$ & 91.66 & 92.37 & 91.41 & 90.64 & 89.56 & 88.27 & 85.05 \\
\hline
\end{tabular}

${ }^{a} \mathrm{Mg} \# 100 \mathrm{Mg} /\left(\mathrm{Mg}+\mathrm{Fe}^{2+}\right)$

$\left.{ }^{\mathrm{b}} \mathrm{Cr} \# 100 \mathrm{Cr}+\mathrm{Al}\right)$

\section{Melt inclusions}

Olivine contains primary two-phase melt inclusions (glass and shrinkage bubbles). They have rounded to negative olivine shapes and may reach $150 \mu \mathrm{m}$ in size. Melts show a broad range in composition, with $\mathrm{MgO}$ varying from 5.5 to $7.6 \mathrm{wt} \%$ (Table 2). Although the melt inclusions have preserved a glassy appearance without daughter crystals inside, their initial composition may have been modified to some extent by a postentrapment overgrowth of olivine. Such a process drastically affects the $\mathrm{Mg}$ \# of the residual melt composition, but does not change other element/oxide ratios of the trapped melt (e.g., $\mathrm{CaO} / \mathrm{Al}_{2} \mathrm{O}_{3}$ or $\mathrm{Na}_{2} \mathrm{O} / \mathrm{K}_{2} \mathrm{O}$ ).
Therefore, the measured compositions have been corrected for the post-trapping crystallization, adding olivine component in the amount required for melt-olivine equilibrium using a numerical modelling of reverse olivine fractionation (program "Petrolog", L.V. Danyushevsky and A.V. Sobolev, personal communication). The $\mathrm{FeO}$ content in the melt and the $\mathrm{Fe}^{2+} / \mathrm{Fe}^{3+}$ ratio are critical parameters in this calculation.

The $\mathrm{FeO}$ content in melt inclusions is rather low $(5.5-8 \mathrm{wt} \%)$, but close to those of the whole rock and the matrix glass (Table 2). The FeO in melt inclusions hosted by Fo $>90.5$ increases from 5.5 to $\sim 7 \mathrm{wt} \%$ as well as the $\mathrm{CaO} / \mathrm{Al}_{2} \mathrm{O}_{3}$ ratio $(0.8-1.15)$, for a $\mathrm{Fo}$ 

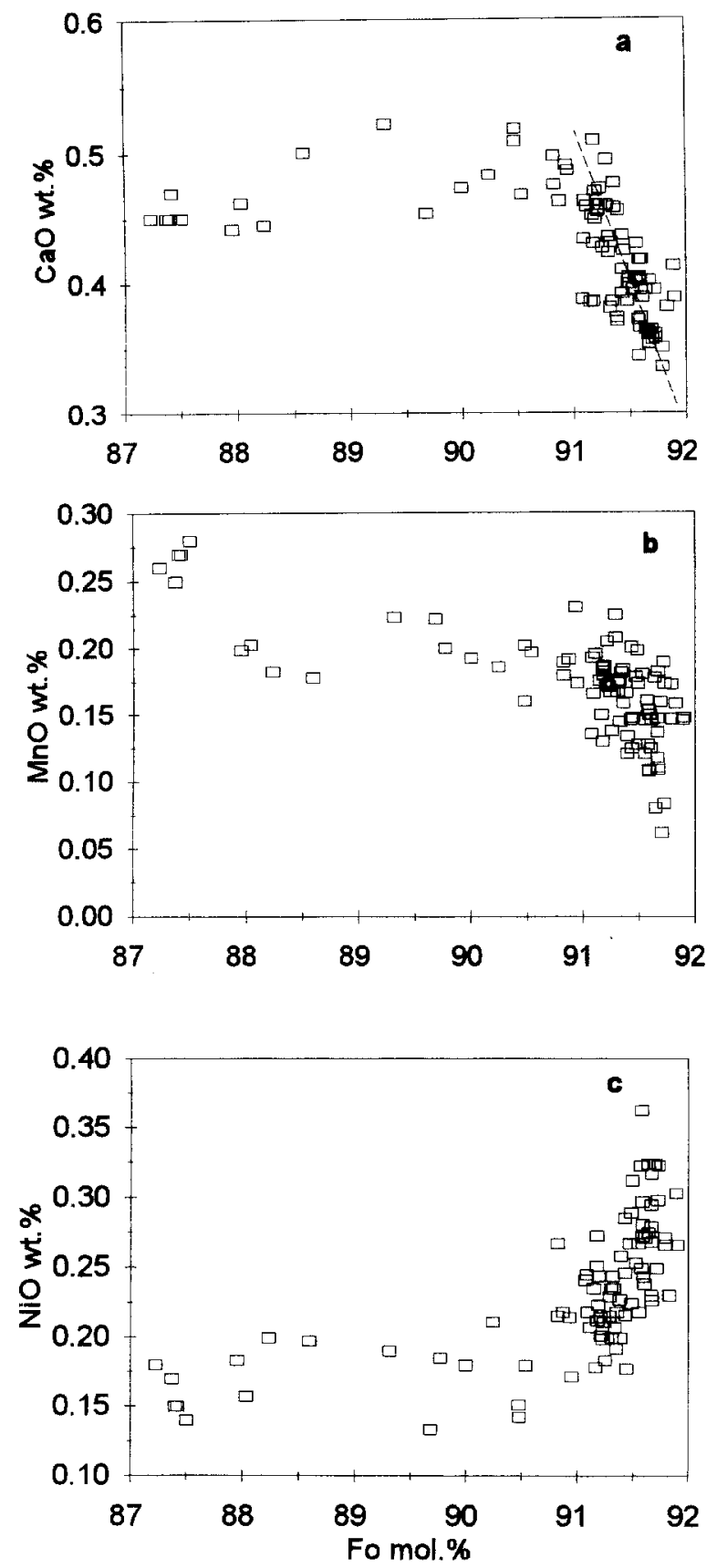

Fig. 1a-c Variations of $\mathrm{CaO}, \mathrm{MnO}, \mathrm{NiO}$ versus $\mathrm{Fo}$ mol $\%$ in olivine phenocrysts and microphenocrysts of (EBOL65) scoria sample. Note the positive correlation of $\mathrm{Fo}$ with $\mathrm{Ni}$ and negative with $\mathrm{Ca}$ and $\mathrm{Mn}$ for olivine with $\mathrm{Fo}>90.5$

decrease from 91.7 to 90.5 (Fig. $4 \mathrm{a}, \mathrm{c}$ ). In melt inclusions trapped in $\mathrm{Fo}<90.5, \mathrm{FeO}$ remains almost constant $(7.4-8 \mathrm{wt} \%)$ and equal to that in matrix glass (Table 2). Therefore, the low FeO content is an inherent property of the magma.

The $\mathrm{Fe}^{2+} / \mathrm{Fe}^{3+}$ ratio in the melt was deduced from experimental data on $\mathrm{Cr}$-spinel-silicate melt equilibria (Maurel and Maurel 1982) through the equation:

$\log _{10}\left(\mathrm{Fe}^{2+} / \mathrm{Fe}^{3+}\right)_{\mathrm{sp}}=0.764 * \log _{10}\left(\mathrm{Fe}^{2+} / \mathrm{Fe}^{3+}\right)_{\text {melt }}-0.343$
The $\mathrm{Fe}^{2+} / \mathrm{Fe}_{\text {melt }}^{3+}=4.8$ and $\mathrm{Fe}^{2+} / \mathrm{Fe}_{\text {melt }}^{3+}$ ranging from 4.8 to 9.3 have been assumed for the melts trapped in olivine $\mathrm{Fo}_{\mathrm{O}}<90.5$ and $\mathrm{Fo}>90.5$, respectively (Fig. 2b). The estimation of Mg-Fe distribution coefficient $K_{D}$ has been based on the following assumptions:

1. Matrix glass composition is in equilibrium with the Fe-richest olivine $\mathrm{Fo}_{87.2}$;

2. The $\mathrm{Fe}^{2+} / \mathrm{Fe}^{3+}$ ratio in the matrix glass is equal 4.8 . The obtained $\mathrm{K}_{\mathrm{D}}=0.27$ appeared to be reasonable (Roeder and Emslie 1970), and it has been applied as a constant value for the recalculation of all melt inclusion compositions. In further presentation and discussion only corrected compositions of melt inclusions will be used.

The equilibrium olivine-melt "dry" temperatures were calculated for the melts in the most magnesian olivines, using Ford et al. (1983) model (Table 2), with a mean value at $1230^{\circ} \mathrm{C}$.

Melt inclusions in olivine show a broad range in $\mathrm{K}_{2} \mathrm{O} / \mathrm{Na}_{2} \mathrm{O}(2-7.3)$ values and $\mathrm{SiO}_{2}(45.3-49.7 \mathrm{wt} \%)$ contents. However, the main variations, as illustrated by $\mathrm{FeO}$ (Fig. 4a), $\mathrm{K}_{2} \mathrm{O}$ (Fig. 4 b) and $\mathrm{CaO} / \mathrm{Al}_{2} \mathrm{O}_{3}$ ratio (Fig. 4c), concern the melts with similar $\mathrm{MgO}$ (8.4-9.7 $\mathrm{wt} \%)$ and $\mathrm{Mg} \#\left(100 \mathrm{Mg} / \mathrm{Mg}+\mathrm{Fe}^{2+}=73-75\right)$, and which are trapped in olivine with a narrow range of composition $\left(\mathrm{Fo}_{92-90.5}\right)$. It has to be noted that the $\mathrm{CaO} / \mathrm{Al}_{2} \mathrm{O}_{3}$ ratio correlates positively with the $\mathrm{CaO}$ content of the host olivine (Fo $>90.5$; Fig. 4d), and cannot be related to the clinopyroxene which crystallizes later. These melt inclusions plot, as a whole, in the field defined by Appleton (1972) for the Roman Province primitive lavas (Fig. 5a), and also they encompass the "undersaturated trend" proposed by Serri et al. (1993). It has to be noted that the melt inclusions with the lowest $\mathrm{K}_{2} \mathrm{O}(2.8 \mathrm{wt} \%)$ mark the transition between KHS and KS fields. All inclusions are characterized by low $\mathrm{Na}_{2} \mathrm{O}(0.9-1.5 \mathrm{wt} \%)$ and $\mathrm{TiO}_{2}(<0.8 \mathrm{wt} \%)$ contents, high $\mathrm{K}_{2} \mathrm{O} / \mathrm{Na}_{2} \mathrm{O}(2-5)$ and $\mathrm{K}_{2} \mathrm{O} / \mathrm{H}_{2} \mathrm{O}(>3)$ ratios. They define negative correlations between pairs of elements, $\quad \mathrm{K}_{2} \mathrm{O}-\mathrm{SiO}_{2}$ (Fig. 5a) and $\mathrm{Al}_{2} \mathrm{O}_{3}-\mathrm{CaO}$ (Fig. 5b). Conversely, $\mathrm{K}_{2} \mathrm{O}$ is positively correlated with $\mathrm{P}_{2} \mathrm{O}_{5}$ (Fig. 6a), $\mathrm{S}$ (Fig. 6b), $\mathrm{Cl}$ (Fig. 6c), and $\mathrm{F}$ (0.13-0.21 wt $\%$; unpublished data from N. Métrich) with nearly constant ratio between pairs of elements. Melts trapped in olivine $\mathrm{Fo}<90.5$ have more evolved compositions, with higher $\mathrm{FeO}$ (Fig. 4a), $\mathrm{K}_{2} \mathrm{O}$ (Fig. 4b) contents. The $\mathrm{CaO} / \mathrm{Al}_{2} \mathrm{O}_{3}$ ratio rapidly decreases (Fig. $4 \mathrm{c}$ ).

The mineralogy and the melt inclusion data evidence two main groups, with a transition corresponding to the olivine $\mathrm{F}_{90.5}$ (Fig. $4 \mathrm{a}-\mathrm{c}$ ). The melt inclusions in olivine (Fo $<90.5$ ) have recorded later evolution that results from diopside-olivine-spinel crystallization, consistent with both $\mathrm{CaO} / \mathrm{Al}_{2} \mathrm{O}_{3}$ and $\mathrm{MgO}$ decrease and $\mathrm{K}_{2} \mathrm{O}$ and $\mathrm{P}_{2} \mathrm{O}_{5}$ increase. Conversely, the melt inclusions in olivine $(\mathrm{Fo}>90.5)$ are considered as 
Table 2 Representative analyses of melt inclusions in olivine and compositions of whole rock, groundmass separates and matrix glass. Minerals were analyzed using SX50 electron microprobe (Camparis, Univ. Paris VI, Paris) at $40 \mathrm{nA}, 20 \mathrm{~s}$ counting time; glass inclusions $10 \mathrm{nA}, 10 \mathrm{~s}$ and $20 \mathrm{~s}$ counting time for major elements; $30 \mathrm{nA}, 30 \mathrm{~s}$ for $\mathrm{Cl}, \mathrm{S}, \mathrm{P}$ and $15 \mu \mathrm{m}$ beam diameter. Sulfur and chlorine were determined with $10 \%$ relative error at the level of $1100 \mathrm{ppm}$ and $3300 \mathrm{ppm}$, respectively (Métrich et al. 1993). Water was analyzed with Cameca ion-microprobe IMS3F (CRPG, Nancy, France). A negative primary ion beam of 2.5 to $5 \mathrm{nA}$ intensity, a spot diameter of $20 \mu \mathrm{m}$, and an energy filtering of $-80 \pm 5 \mathrm{eV}$ were used. Count rates were normalized to ${ }^{30} \mathrm{Si}$ peak. The ${ }^{27} \mathrm{Al} /{ }^{30} \mathrm{Si}$ ratio was also measured to control any host mineral contamination. The calibration curve between wt $\% \mathrm{H}_{2} \mathrm{O} / \mathrm{wt} \% \mathrm{SiO}_{2}$ and ${ }^{1} \mathrm{H} /{ }^{30} \mathrm{Si}$ ratio was obtained on glass standards containing between 0.19 and 5.03 wt $\% \mathrm{H}_{2} \mathrm{O}$ (A. Sobolev and $\mathrm{M}$. Chaussidon submitted), with $20 \%$ relative error on $\mathrm{H}_{2} \mathrm{O}$ measurement. (n.d. not determined)

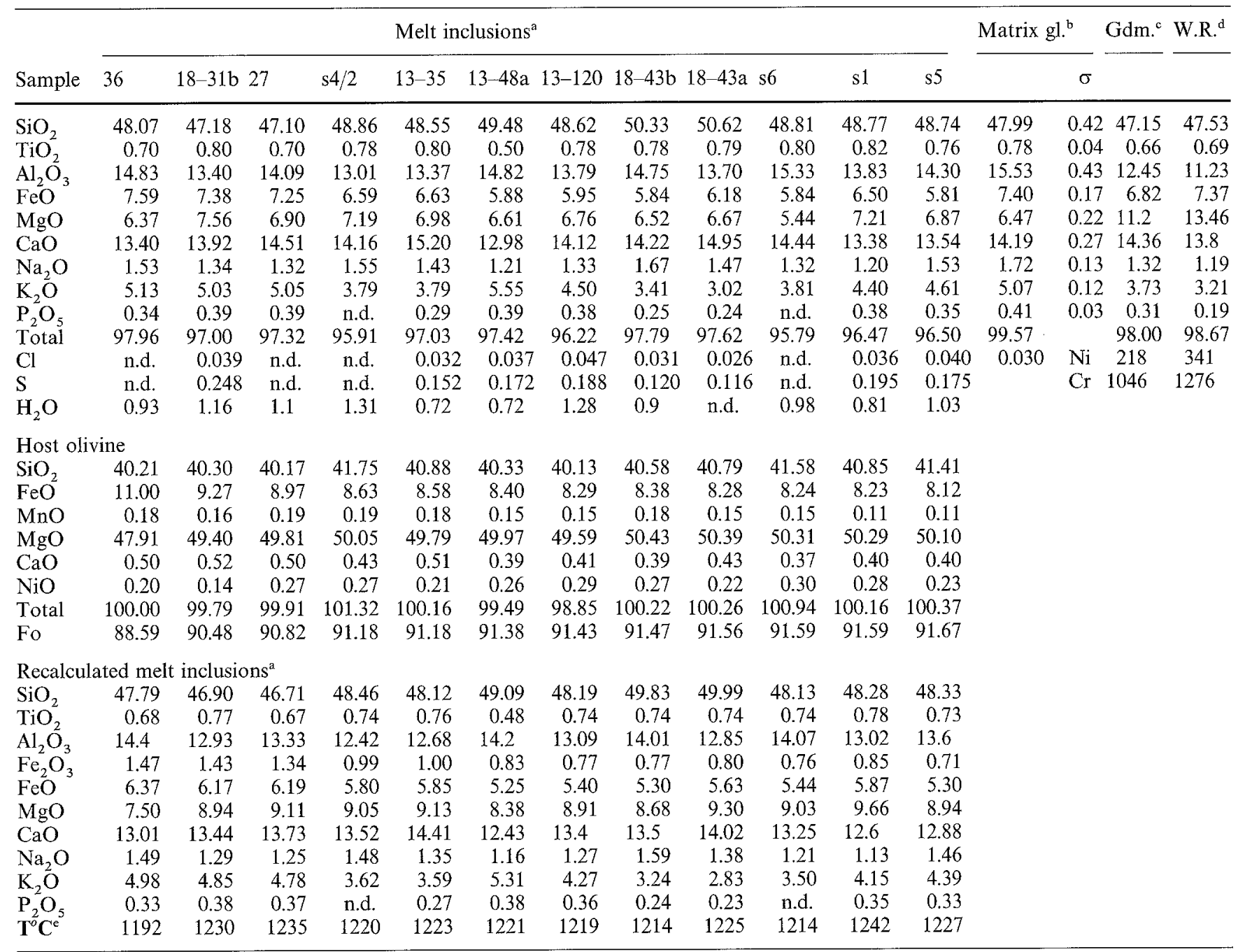

${ }^{a}$ Melt inclusions in olivine before and after recalculation (see text for details)

${ }^{b}$ Matrix glass: average of 14 points, and standard deviation (s)

${ }^{\circ} \mathrm{Gdm}$; groundmass separates (ICP; CRPG, Nancy)

${ }^{\mathrm{d}}$ W.R. whole rock (EBOL65; Cioni 1993)

${ }^{\text {e }} T^{\circ} \mathrm{C}$ : calculated temperatures of olivine - anhydrous melt equilibria (Ford et al. 1983)

representative of primary magmas in equilibrium with early olivine-spinel paragenesis.

\section{Discussion}

Continuous spectrum of primary melts

Various types of lavas (with high $\mathrm{Mg} \#, \mathrm{Ni}$ and $\mathrm{Cr}$ values) have been discussed as a possible equivalent of the primary magmas. For example, in the Vulsini area, leucite-basanite (LBSN; $\mathrm{MgO}=10-13 \mathrm{wt} \%, \mathrm{Ni}=$ $180-260 \mathrm{ppm}, \mathrm{Cr}=600-900 \mathrm{ppm}$, and similar to the studied sample EBOL65) is considered as the best candidate for an unfractionated mantle-derived magma (Cundari and Le Maître 1970; Rogers et al. 1985; Varekamp and Kalamarides 1989). Mg-leucitites and leucite-tephrites $(\mathrm{MgO} \sim 9 \mathrm{wt} \%$; $\mathrm{CaO}=13-14 \mathrm{wt} \%)$ were also discussed as representative of the parental magmas of the HKS series of Vulsini area (Civetta et al. 1984, Rogers et al. 1985; Ferrara et al. 1986; Conticelli 

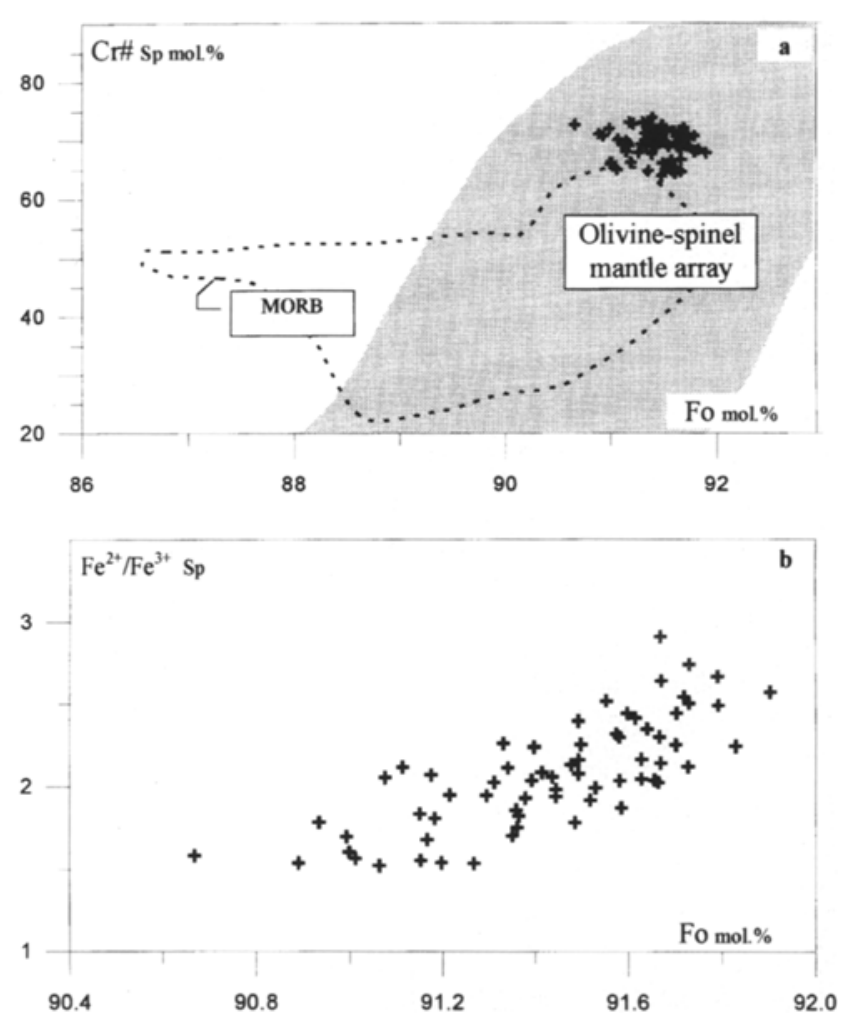

Fig. 2a, b Relationships between olivine phenocrysts and their Crspinel inclusions. a Olivine-spinel mantle array (stippled area) from Arai (1987); MORB field from V. Kamenetsky and A.J. Crawford (unpublished data) and Arai $(1992,1994)$; $\boldsymbol{b}$ The $\mathrm{Fe}^{2+} / \mathrm{Fe}^{3+}$ ratio of spinel is calculated on the basis of stoichiometry

and Peccerillo 1992). On the other hand, Appleton (1972) considered the parental magmas to be certainly more basic than the most primitive rocks.

It has to be noted that these rocks may be aphyric (e.g., Civetta et al. 1984) to slightly porphyric or most likely cumulative (e.g., rocks with $\mathrm{MgO} \sim 14 \mathrm{wt} \%$ ) and that only HKS primitive rocks were recognized in the Vulsini area (Rogers et al. 1985; Civetta et al. 1984; Coltorti et al. 1991; Conticelli and Peccerillo 1992, Cioni 1993). Conversely, in the other parts of the RCP, (e.g., Roccamonfina, Appleton 1972; Giannetti and Ellam 1994; or Ernici, Civetta et al. 1981), the rocks with high $\mathrm{Mg}$ \# have been found to belong to the KS group only. Coltorti et al. (1991) suggested that some rocks that have $\mathrm{MgO}=8.5-9.2 \mathrm{wt} \%$ and contain high-magnesian olivine $\left(\mathrm{F}_{88}{ }_{81}\right)$ "may represent near-primary compositions which have suffered only slight degrees of differentiation".

Our data record $\mathrm{Cr}$-spinel as the only liquidus phase crystallized together with olivine $\left(\mathrm{F}_{92-90.5}\right)$, as the clinopyroxene appeared later. The compositions of the most primitive olivine and $\mathrm{Cr}$-spinel from the (EBOL65) scoria are within the mantle array defined by Arai (1987) for spinel lherzolites and spinel harzburgites (Fig. 2a) and indicate unambiguously the mantle origin of their parental melts. Accordingly, melts trap-
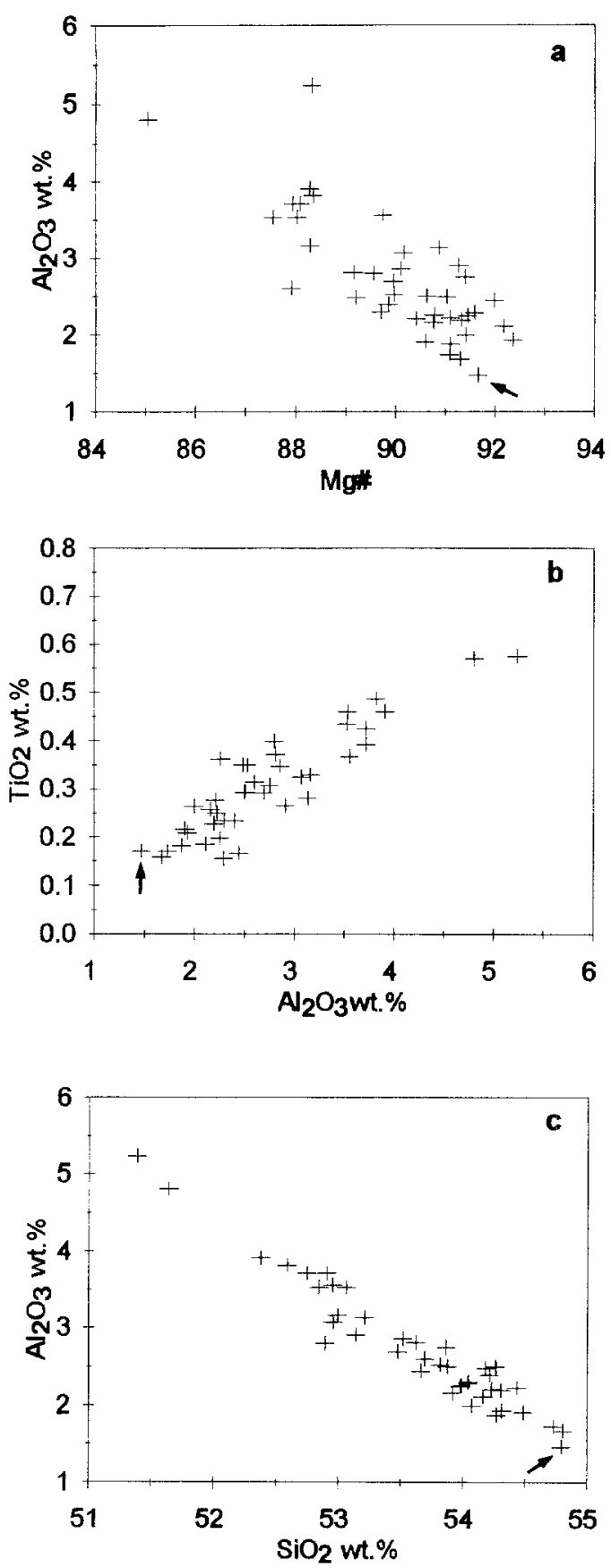

Fig. 3 Compositions of the clinopyroxene phenocrysts and microphenocrysts in scoria EBOL65, arrow points to clinopyroxene inclusion in olivine (Table 1 , no. 15)

ped by these mineral phases should represent primary melts. Relatively low abundance of $\mathrm{MgO}(8.4-9.7 \mathrm{wt} \%$ ) coupled with extremely low $\mathrm{FeO}^{*}$ (total $\mathrm{Fe}$ as $\mathrm{FeO}$ ) values $(6-7.5 \mathrm{wt} \%)$ governs the high "primary" $\mathrm{Mg} \#$ (73-75) of studied melts. Their high $\mathrm{CaO} / \mathrm{Al}_{2} \mathrm{O}_{3}$ ratios (1.15-0.8), also indicate their unfractionated nature. Moreover, neither the range in composition of melts in olivine ( $\mathrm{FO}_{92-90.5}$; Fig. 4) nor the $\mathrm{SiO}_{2}-\mathrm{K}_{2} \mathrm{O}, \mathrm{Al}_{2} \mathrm{O}_{3}$ $\mathrm{CaO}$ negative correlations at almost constant $\mathrm{Mg \#}$ (Fig. 5) can be explained by any crystallization process. 

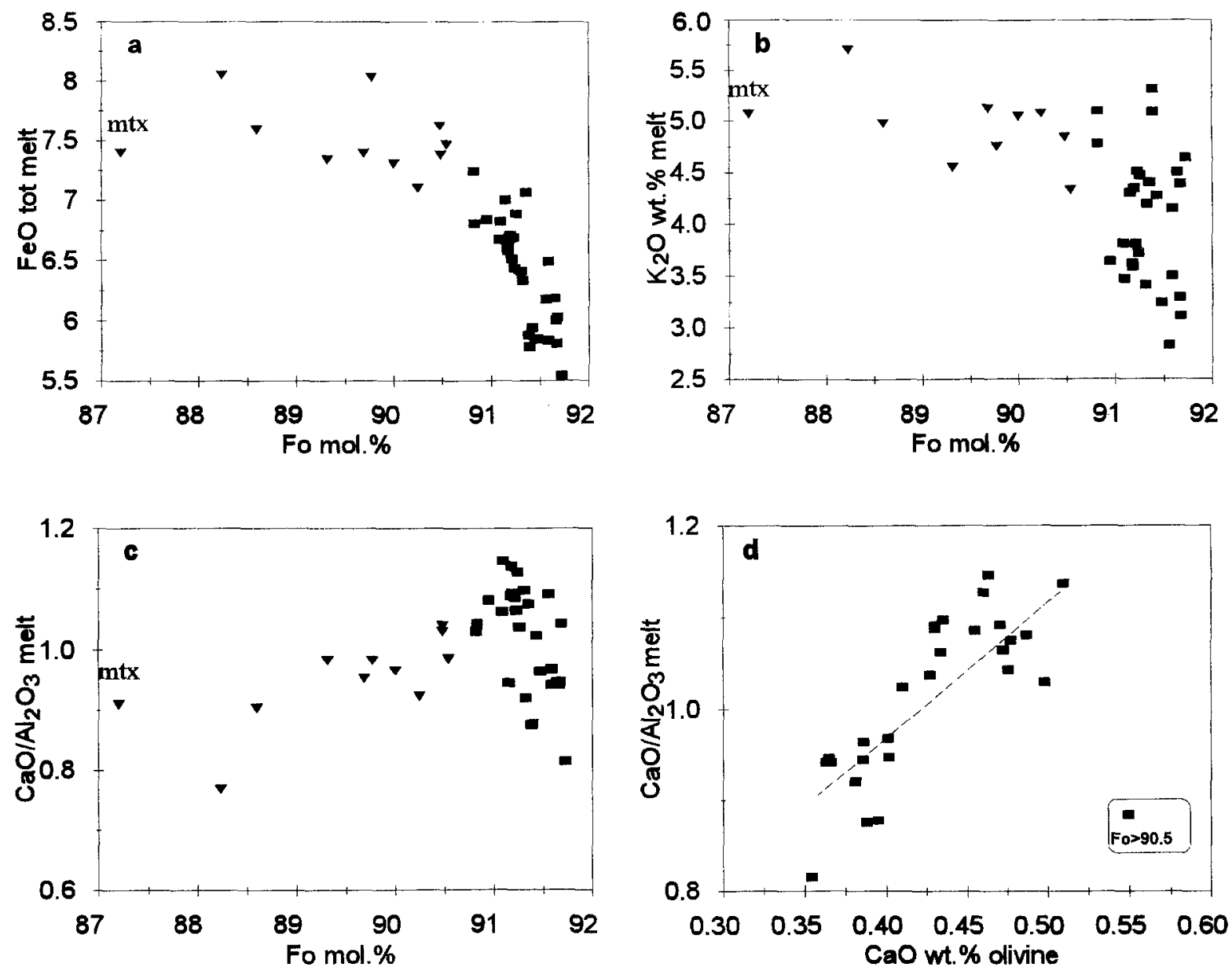

Fig. 4 Relationships between host olivine and melt inclusions. The melt inclusion compositions are recalculated (Table 2, see text for details). Matrix glass composition is designated $m t x$ (Table 2), the olivine $\left(\mathrm{Fo}_{87.2}\right)$ was assumed to be in equilibrium with matrix glass

These results testify to the existence of a continuous spectrum of primary melts.

Independent support for this assertion comes from evaluation of trace element $(\mathrm{Ca}, \mathrm{Ni}, \mathrm{Mn})$ systematics in olivine $\left(\mathrm{Fo}_{92}-90.5\right)$. Positive correlation of $\mathrm{Fo}$ with $\mathrm{Ni}$ and negative with $\mathrm{Ca}$ and $\mathrm{Mn}$ is a typical feature of high-magnesian olivine formed by fractional crystallization (Fig. 1), but usually these trends are not so dramatically steep (Sigurdsson et al. 1993) as in the case of Vulsini olivine. The positive correlation between $\mathrm{CaO}$ in Vulsini rocks and olivine phenocrysts has also been noticed by Holm (1982), who explained this dependence by the dominant effect of calcium in the magmas. The partitioning of trace elements between silicate melt and olivine still remains poorly studied, though it is believed that $\mathrm{Ca}$ content in olivine is strongly dependent on calcium (Jurewicz and Watson 1988; Watson 1979) and iron (Jurewicz and Watson 1988 ) in the melt. Ignoring other parameters, such as pressure and temperature of crystallization, which are supposed to be similar for all studied olivines, it is

worth noticing that strong positive correlations of $\mathrm{CaO}$ in olivine $\mathrm{Fo}_{92-90.5}$ with $\mathrm{CaO} / \mathrm{Al}_{2} \mathrm{O}_{3}$ and $\mathrm{FeO} *$ in the melts (Fig. 4a, b, d) support the experimental data and clearly reflect the actual variations in the composition of the crystallizing melts.

Mineralogy and melt inclusion data thus show the existence of different primary melts. They lie on the same trend of $\mathrm{SiO}_{2}$ versus $\mathrm{K}_{2} \mathrm{O}$ (Fig. 5a) as the primitive rocks considered by many authors as "near-liquid" compositions (e.g. Appleton 1972). They also belong to the "undersaturated trend" (group II, defined by Serri et al. 1993), which contains all the relatively primitive KS, HKS and ultra-potassic (kamafugite) rocks. Therefore, our main conclusion is consistent with the assumption of other authors (Appleton 1972; Varekamp 1980 ) that the initial differences in a parental composition resulted in high compositional variability of rocks of the northern Roman Province.

Mixing between different magmas similar in composition to HKS and KS rocks was proposed on the basis of general chemical and isotopic constraints (e.g., Ferrara et al. 1986). The same conception has been also suggested by Civetta et al. (1981), but they criticised it themselves on account of compositional gap between the two series. Compositions of melt inclusions, plotted on $\mathrm{SiO}_{2}$ versus $\mathrm{K}_{2} \mathrm{O}$ (Fig. 5a), are consistent with the "mixing line" of possible parental magmas which was 

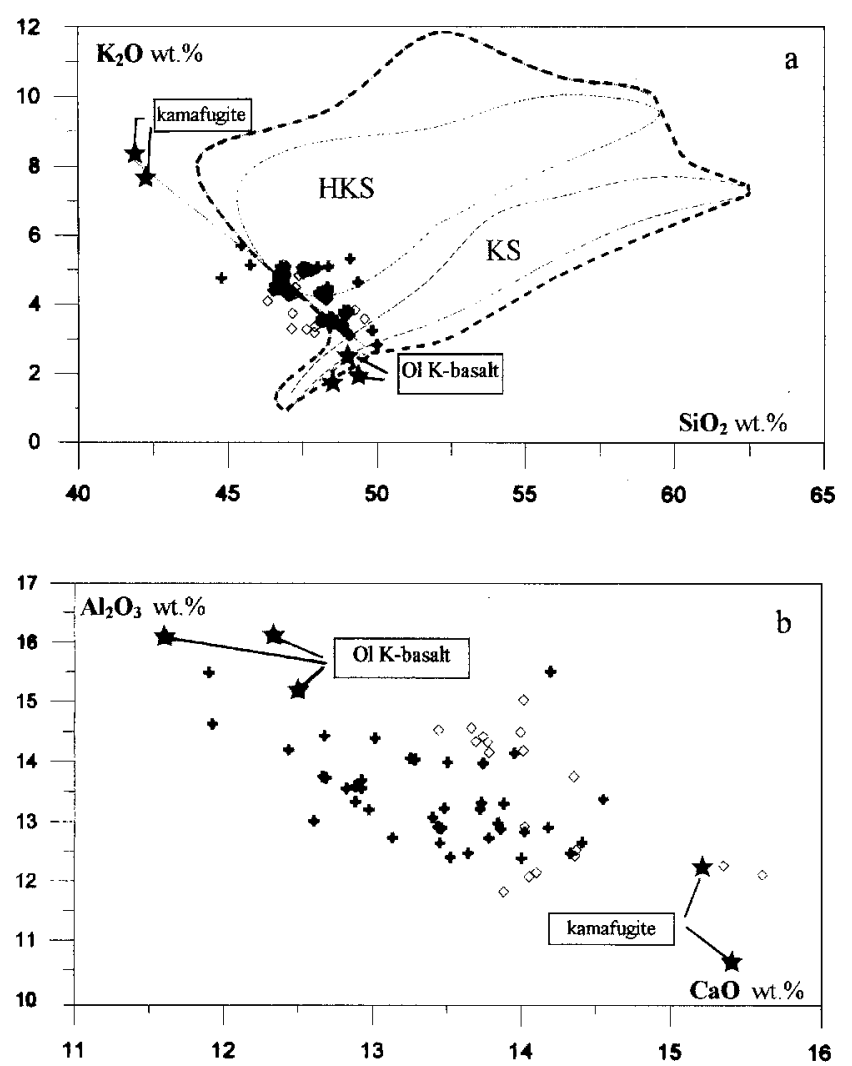

Fig. 5a, b Comparison between melt inclusions (recalculated compositions) and rocks from the northern part of the Roman Province. Symbols: $(+)$ melt inclusions; $(\diamond)$ the most primitive Si-undersaturated rocks from Vulsini (Holm et al. 1982; Civetta et al. 1984; Rogers et al. 1985; Coltorti et al 1991; Conticelli and Peccerillo 1992; Rogers 1992), ( $\star$ ) Kamafugite from San Venanzo (Conticelli and Peccerillo 1992; Holm et al. 1982) and olivine K-basalts from Roccamonfina (Appleton 1972; Giannetti and Ellam 1994). a Broken line marks the general field for all rocks of the RCP; all fields are from Appleton (1972)

tentatively proposed by Appleton (1972). The olivine K-basalts (Appleton 1972; Civetta et al. 1981; Gianetti and Ellam 1994) and ultra-K leucite-olivine melilitite (kamafugite) from San Venanzo (Holm et al. 1982; Conticelli and Peccerillo 1992) could represent the endmembers on this mixing line, and they outline the trend consistent with Vulsini primary melts on the plot $\mathrm{CaO}$ versus $\mathrm{Al}_{2} \mathrm{O}_{3}$ (Fig. 5b). However, the $\mathrm{KS}$ primitive rocks from other volcanic complexes are different in trace element systematics and in having lower $\mathrm{SiO}_{2}$ and $\mathrm{K}_{2} \mathrm{O}$ (e.g., Roccamonfina; Gianetti and Ellam 1994) than Vulsini rocks and melts respectively. Thus, the proposed end-members are not adequately applicable to the petrogenesis of rocks from RCP on the whole.

Our data demonstrate that highly variable primary melts can be emitted during a single, volumetrically small eruption. These melts are characterized by very high $\mathrm{Mg} \#(>70)$ and low $\mathrm{TiO}_{2}(0.6-0.8 \mathrm{wt} \%)$ and $\mathrm{Na}_{2} \mathrm{O}(0.9-1.5 \mathrm{wt} \%)$ contents, as are the most primitive HKS and KS rocks which are also closely associated with each other, both in space and time (e.g., Coltorti
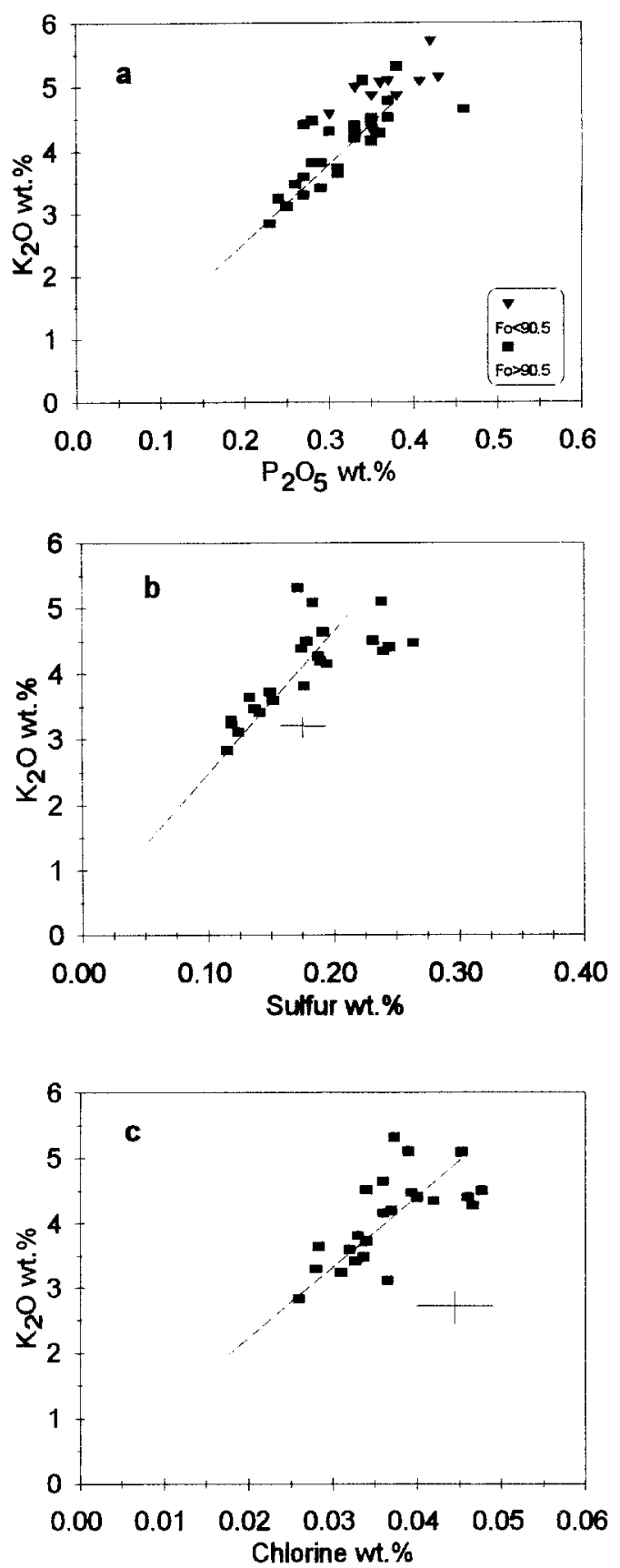

Fig. 6 Relationships between $\mathrm{K}_{2} \mathrm{O}$ and $\mathrm{P}_{2} \mathrm{O}_{5}$ (a); sulfur (b); chlorine (c) in melt inclusions. Note the near-constant $\mathrm{K}_{2} \mathrm{O} /$ element ratios

et al. 1991). The independent support of close genetic relationships between melts parental for kamafugite, HKS and KS of the Vulsini area comes from the assessment of isotope and trace element data (e.g., Holm and Munksgaard 1982; Conticelli and Peccerillo 1992), which show the similarity of $\mathrm{Sr}$ isotope ratios and trace element patterns for all the above mentioned rocks.

Consideration of primary melts as a continuous spectrum may shed light on further evaluation of the genesis of primary melts, especially in interpretation of 
the compositional spectrum of rocks from the Vulsini area and the northern part of the Roman Province.

Implications for the mantle source

There is a general consensus that the compositional diversity demonstrated by the most primitive rocks of northern Roman Province is due to the melting of a heterogeneous source. This is traditionally considered to be a mantle peridotite, which contributes the volumetric mass of magmas, plus a subduction-related component(s) (either $\mathrm{H}_{2} \mathrm{O}$-bearing fluid or/and silicate or carbonatite melt) which supplies the bulk of incompatible and volatile elements.

As we deal with the primary melt, that is a melt, that has not experienced any changes since the last equilibration with the mantle source, we can exclude from the consideration assimilation of crustal material by magmas en route to the surface. Therefore, their geochemical features may be applied directly to the characterization of the mantle source region, the nature of enrichment and the processes of melting.

Evaluation of $\mathrm{Ta} / \mathrm{Yb}$ (Rogers et al. 1985) or $\mathrm{Nb} / \mathrm{Y}$ and $\mathrm{Nb} / \mathrm{Zr}$ (Serri 1990) ratios lead these authors to conclude that pre-enriched mantle source beneath the Roman Province resembles that of MORB(Midocean-ridge basalt)-type mantle. The low $\mathrm{TiO}_{2}$ and especially $\mathrm{Na}_{2} \mathrm{O}$ contents of the Vulsini primary melts suggest a very depleted mantle source, which could have been even more depleted prior to the metasomatism. Mineralogical data demonstrate that olivine is as Fo-rich as in the most primitive MORBs (Fig. 7) and that spinels are more enriched in $\mathrm{Cr}_{2} \mathrm{O}_{3}$ and depleted in $\mathrm{Al}_{2} \mathrm{O}_{3}$ than those of MORBs (Fig. 2a). However, the calculated temperature of crystallization of the Vulsini primary melts is significantly lower than that of typical OIB (ocean-island basalt) or MORB and akin to the temperature of kamafugite of the East African rift (Fig. 7). We therefore conclude that the mantle source, prior to enrichment, was cold, refractory lithospheric mantle.

The origin and composition of the subduction-related component which caused the mantle metasomatism have been extensively debated. A few remarks regarding this matter should be made:

1. The continuous compositional spectrum between KS and HKS melts, as demonstrated on the basis of melt inclusions, their coexistence within a single volcanic event, and even the geochemical similarity between KS and HKS rocks (e.g., Conticelli and Peccerillo 1992), reinforce the idea that the observed chemical differences between these melts do not necessarily reflect different processes of enrichment (Rogers 1992). 2. The enrichment of the mantle source in potassium and related elements is probably accompanied with the addition of calcium (Serri et al. 1993; Conticelli and

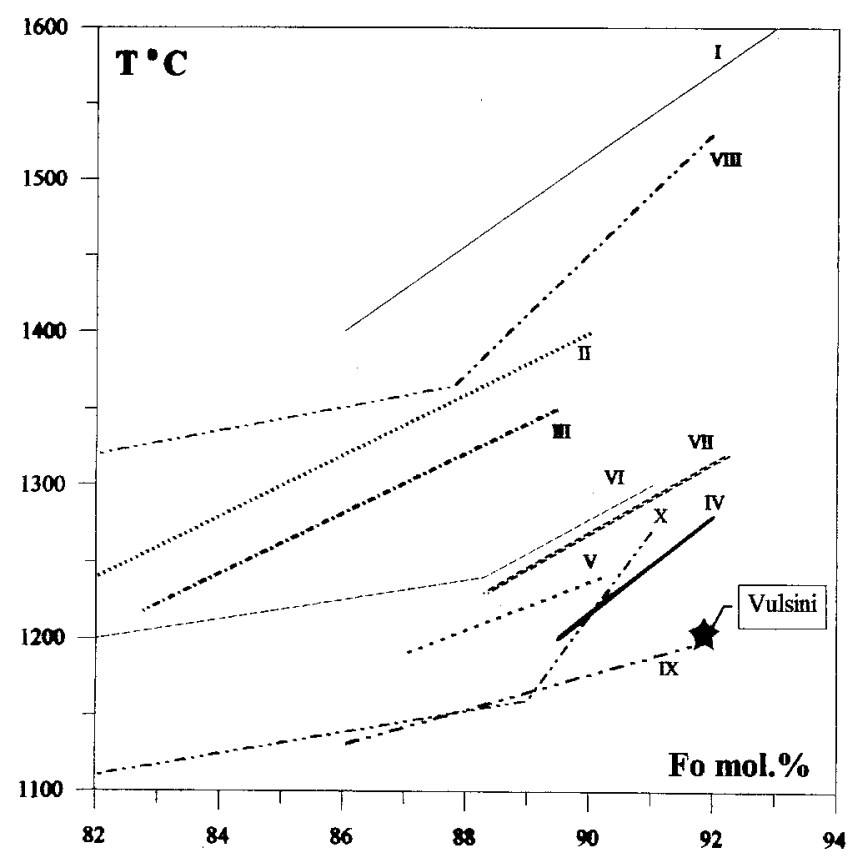

Fig. 7 Comparison between temperature of the Vulsini primary melts and crystallization temperatures of other mantle-derived melts. Temperature for Vulsini is the average temperature of calculated olivine $(\mathrm{Fo}>90.5)$-anhydrous melt equilibria (Table 2). Taking into account 1 wt. $\% \mathrm{H}_{2} \mathrm{O}$ content (Table 2), this average "dry" temperature $1230^{\circ} \mathrm{C}$ is reduced to $1200^{\circ} \mathrm{C}$ (Danyushevsky et al. 1992). The trends (I-X) represent Fo-temperature relationships (Sobolev et al. 1989a) revealed from homogenization experiments with melt inclusions in olivine. $I$ ultramafic volcanics (meymechites) from Siberia (Sobolev et al. 1992), II Hawaiian tholeiites (Sobolev and Nikogosian 1994), III oceanites from Reunion, Indian Ocean (Sobolev and Nikogosian 1994), IV MOR tholeiites from FAMOUS area, Atlantic Ocean (V. Kamenetsky unpublished data), $V$ MOR tholeiites from Vema Fracture zone, Atlantic Ocean (Sobolev et al. 1989b), VI alkaline basalts from Iceland (Gurenko et al. 1992a), VII tholeiites from Iceland (Gurenko et al. 1988, 1991), VIII Na-alkaline basalts from East African rift (Gurenko et al. 1992b), IX kamafugites from East African rift (Gurenko et a1. 1989), $X$ lower pillow lavas (LPL) of Troodos, Cyprus (Portnyagin et al. 1993)

Peccerillo 1992), resulting in an unusually high $\mathrm{Ca} / \mathrm{Al}$ ratio of the melts well above those in any known MORBs composition. From low $\mathrm{Na}_{2} \mathrm{O}$ and $\mathrm{TiO}_{2}$ abundances in both HKS and KS melts we anticipate that these elements were not much introduced via the metasomatic agent.

3. The apparent enrichment of magmas in $\mathrm{K}_{2} \mathrm{O}, \mathrm{H}_{2} \mathrm{O}$ and $\mathrm{CaO}$, led many authors to propose a phlogopiteclinopyroxene bearing mantle source (Conticelli and Peccerillo 1992; Beccaluva et al. 1991; Foley 1992a, b; Holm et al. 1982; Rogers et al. 1985; Rogers 1992; Serri et al. 1993). This is also supported by the finding of mica-pyroxenite nodules in lavas of the Roman Province (Appleton 1972; Cundari and Le Maître 1970; Varekamp 1983). These minerals are believed to represent the products of mantle metasomatism (e.g., Wyllie and Sekine 1982) caused by interaction with subduction-related or lithospheric fluids or/and melts. While 
these non-peridotitic mineral assemblages are presumably distributed within restricted areas in the mantle (e.g., veins), they are responsible for the mantle inhomogeneity and, therefore, for the variety of primary liquids produced by melting of such a mantle.

The model of melting of a veined mantle, recently discussed by Foley (1992b), is able to explain the compositional features of Vulsini primary melts. According to this model, the melting begins in the $\mathrm{Cpx}+\mathrm{Phl}-$ bearing veins ("V-component") due to high concentration of incompatible elements and volatiles, producing magmas unusually enriched in potassium and LIL elements, as well as volatiles and $\mathrm{Ca}$, but Si-undersaturated. As melting proceeds, very small fractions of melt can escape and rise to the surface to form HKS rocks. The other batches of initially or subsequently produced melts penetrate wall-rock peridotite ("Wcomponent") and gradually change their composition as a result of peridotite dissolution and extraction of more refractory "peridotitic" components. The further melting and decreasing of vein/wall-rock ratio would be followed by dilution of originally enriched melts and their shifting toward more common basaltic composition (KS melts). It is worthwhile to emphasize that all melts formed, despite the difference in extent of interaction with wall peridotite, should be still in equilibrium with their mantle source (i.e., melt $\mathrm{Fe} / \mathrm{Mg}$ ratios should be fully buffered by residual olivine, according to Bèdard 1989) and retain the features of primary melts. The Vulsini HK and $\mathrm{K}$ melts, as well as a kamafugite from San Venanzo (Holm and Munksgaard 1982; Conticelli and Peccerillo 1992) are in equilibrium with high-magnesian olivine up to $\mathrm{Fo}_{92}$, and thus, very likely with the source mineralogy.

Due to very low Sr content in the wall-rock peridotite, the effect of Sr dilution in the melt will have very little influence on $\mathrm{Sr}$ isotope ratios. This conclusion is very consistent with the ${ }^{87} \mathrm{Sr} /{ }^{86} \mathrm{Sr}$ ratios $(0.710-0.711)$ similar in HKS, KS rocks and kamafugite from Vulsini area (Holm and Munksgaard 1982; Conticelli and Peccerillo 1992).

On the other hand, the processes of dilution, resulting in the observed correlations between $\mathrm{K}_{2} \mathrm{O}$ and $\mathrm{P}_{2} \mathrm{O}_{5}, \mathrm{Cl}, \mathrm{S}$ (Fig. 6), or LIL elements (e.g., Conticelli and Peccerillo 1992) and $\mathrm{SiO}_{2}$ (Fig. 5a), mainly support the vein-peridotite melting mechanisms in the origin of potassic melts, as proposed by Foley $(1992 b, 1993)$.

\section{Conclusions}

1. The exceptionally primitive compositions of olivine and spinel, from the LBSN scoria (Montefiascone, Vulsini area), manifest the primary nature of melts trapped by these phenocrysts.

2. The compositions of the primary melts define a continuous trend between the most primitive HKS and KS Si-undersaturated rocks.
3. The existence of such a diversity of primary melts, within the same area and the same eruption, testifies to their segregation from the same metasomatized refractory mantle source. Their possible mixing, after segregation, can be considered as an additional process responsible for the broad diversity of the rocks from the nothern part of the Roman Province.

Acknowledgements We thank M. Gasparon for his constructive criticism, R. Clocchiatti for useful discussion, John Snow for comments on the first draft and his patience while improving the English, Leonid Danyushevsky for making the program "Petrolog" available to us; M. Chaussidon and E. Deloule for their help in analyzing $\mathrm{H}_{2} \mathrm{O}$ by SIMS. V.K. carried out this work during his post-doctoral fellowship at Pierre Süe laboratory. This work was partly supported by CNR-CNRS collaboration program $(91 / 656, \mathrm{~N} 30)$.

\section{References}

Appleton JD (1972) Petrogenesis of potassium-rich lavas from the Roccamonfina Volcano, Roman Region, Italy. J Petrol $13: 425-456$

Arai S (1987) An estimation of the least depleted spinel peridotite on the basis of olivine-spinel mantle array. Neues Jahrb Mineral Monatsh 8:347-354

Arai S (1992) Chemistry of chromian spinel in volcanic rocks as a potential guide to magma chemistry. Mineral Mag 56:173-184

Arai S (1994) Compositional variation of olivine-chromian spinel in $\mathrm{Mg}$-rich magmas as a guide to their residual spinel peridotites. J Volcanol Geothermal Res 59:279-293

Beccaluva L, Di Girolamo P, Serri G (1991) Petrogenesis and tectonic setting of the Roman Volcanic Province. Lithos 26:191-221

Bèdard JH (1989) Disequilibrium mantle melting. Earth Planet Sci Lett 91:359-366

Cioni R (1993) Il complesso di Bolsena e il vulcanismo alcalinopotassico del Lazio settentrionale. $\mathrm{PhD}$ thesis, Pisa

Civetta L, Innocenti F, Manetti P, Peccerillo A, Poli G (1981) Geochemical characteristics of potassic volcanics from Mts. Ernici (Southern Latium, Italy). Contrib Mineral Petrol 78:37-47

Civetta L, Del Carmine P, Manetti P, Peccerillo A, Poli G (1984) Petrology, geochemistry and Sr-isotope characteristics of lavas from the area of Commenda (Mts. Vulsini, Italy). Bull Volcanol 47-3:581-595

Coltorti M, Di Battistini G, Nappi G, Renzulli A, Zeda O (1991) Structural setting and magmatic evolution of Montefiascone Volcanic Complex, Vulsini District, central Italy. J Volcanol Geothermal Res 46:99-124

Conticelli S, Francalanci L, Santo AP (1991) Petrology of final stage Latera lavas, Vulsini Mts.: mineralogical, geochemical and Srisotopic data and their bearing on the genesis of some potassic magmas in Central Italy. J Volcanol Geotherm Res 46:187-212

Conticelli S, Peccerillo A (1992) Petrology and geochemistry of potassic and ultrapotassic volcanism in central Italy: petrogenesis and inferences on the evolution of the mantle sources. Lithos $28: 221-240$

Cundari A, Le Maitre RW (1970) On the petrogeny of the leucitebearing rocks of the Roman and Birunga volcanic regions. J Petrol 11:33-47

Danyushevsky LV, Sobolev AV, Kononkova NN (1992) Methods of studying magma inclusions in minerals during investigations on water-bearing primitive mantle melts (Tonga trench boninites). Geochem Int 29:48-62

Ferrara G, Priete-Martinez M, Taylor HP, Tonarini S, Turi B (1986) Evidence for crustal assimilation, mixing of magmas and a ${ }^{87} \mathrm{Sr}$ rich upper mantle. Contrib Mineral Petrol 92:269-280 
Foley S (1992a) Petrological characterization of the source components of potassic magmas: geochemical and experimental constraints. Lithos 28:187-204

Foley S (1992b) Vein-plus-wall-rock melting mechanism in the lithosphere and the origin of potassic alkaline magmas. Lithos 28:435-453

Foley S (1993) An experimental study of olivine lamproite: first results from the diamond stability field. Geochim Cosmochim Acta 57:483-489

Ford CE, Russel DG, Graven JA, Fisk MR (1983) Olivine-liquid equilibria: temperature, pressure and composition dependence of the crystal/liquid cation partition coefficients for $\mathrm{Mg}, \mathrm{Fe}^{2+}, \mathrm{Ca}$ and Mn. J Petrol 24:256-265

Frey FA, Green DH, Roy SD (1978) Integrated models of basalt petrogenesis: a study of quartz tholeiites to olivine melilitites from southeastern Australia utilizing geochemical and experimental petrological data. J Petrol 19:463-513

Ghiara MR, Lirer L (1977) Mineralogy and geochemistry of the "Low Potassium" series of the Roccamonfina volcanic suite (Campania, South Italy). Bull Volcanol 40:39-56

Giannetti B, Ellam R (1994) The primitive lavas of Roccamonfina volcano, Roman region, Italy: new constraints on melting processes and source mineralogy. Contrib Mineral Petrol 116:21-31

Gurenko AA, Sobolev AV, Polyakov AI, Kononkova NN (1988) Primary melt of rift tholeiites of Iceland: composition and conditions of crystallization. Trans (Doklady) USSR Acad Sci 301:109-113

Gurenko AA, Sobolev AV, Kononkova NN (1989) New petrologic data on ugandites from East-African rift, as revealed by study of magmatic inclusions in minerals. Trans (Doklady) USSR Acad Sci 305:130-134

Gurenko AA, Sobolev AV, Kononkova NN (1991) Petrology of the primary magma of the Reykjanes Peninsula rift tholeiites. Geochem Inter 28:58-71

Gurenko AA, Sobolev AV, Kononkova NN (1992a) New petrological data on Icelandic rift alkali basalts. Geochem Inter 29:41-53

Gurenko AA, Sobolev AV, Kononkova NN (1992b) Petrology of Na-alkaline basaltic magmatism of East-African rift as revealed by study of magmatic inclusions in minerals. Doklady USSR Acad Sci 322:360-365

Holm PM (1982) Mineral chemistry of perpotassic lavas of the Vulsinian district, Roman Province, Italy. Mineral Mag 46:379-386

Holm PM, Lou S, Nielsen A (1982) The geochemistry and petrogenesis of the lavas of the Vulsinian district, Roman Province, Central Italy. Contrib Mineral Petrol 80:367-378

Holm PM, Munksgaard NC (1982) Evidence for mantle metasomatism: an oxygen and strontium isotope study of the Vulsinian district, Central Italy. Earth Planet Sci Lett 60:376-388

Jurewicz AJG, Watson EB (1988) Cations in olivine, 1: Calcium partitioning and calcium-magnesium distribution between olivines and coexisting melts, with petrologic applications. Contrib Mineral Petrol 99:176-185

Marianelli P, Métrich N, Santacroce R, Sbrana A (1994) Mafic magma batches at Vesuvius: a glass inclusion approach to the modalities of feeding stratovolcanoes. Contrib Mineral Petrol (in press)

Marini M, Nappi G (1986) Origin and evolution of the Montefiascone caldera (Vulsini volcanoes). Mem Soc Geol Ital 25:657-665

Maurel C, Maurel P (1982) Etude expérimentale de l'équilibre $\mathrm{Fe}^{2+}$. $\mathrm{Fe}^{3+}$ dans les spinelles chromifères et les liquides silicatés basiques coexistants, à $1 \mathrm{~atm}$. CR Acad Sci Paris 295:209-212

Métrich N, Clocchiatti R, Mosbah M, Chaussidon M (1993) The 1989-1990 activity of Etna. magma mingling and ascent of a $\mathrm{H}_{2} \mathrm{O}-\mathrm{Cl}$-S-rich basaltic magma. evidence from melt inclusions. J Volcanol Geothermal Res 59:131-144
Peccerillo A, Poli G, Tolomeo L (1984) Genesis, evolution and tectonic significance of K-rich volcanics from the Alban Hills (Roman comagmatic region) as inferred from trace element geochemistry. Contrib Mineral Petrol 86:230-240

Peccerillo A, Poli G, Serri G (1988) Petrogenesis of orenditic and kamafugitic rocks from Central Italy. Can Mineral 26:45-65

Portnyagin MV, Kamenetsky VS, Sobolev AV, Danyushevsky LV, Dmitriev LV (1993) The new type of the primary magmas of Troodos Complex (Cyprus). Doklady Russ Acad Sci $333: 370-375$

Roeder PL, Emslie RF (1970) Olivine-liquid equilibrium. Contrib Mineral Petrol 29:275-289

Rogers NW (1992) Potassic magmatism as a key to trace-element enrichment processes in the upper mantle. J Volcanol Geothermal Res 50:85-99

Rogers NW, Hawkesworth CJ, Parker RJ, March JS (1985) The geochemistry of potassic lavas from Vulsini, central Italy and implications for mantle enrichment processes beneath the Roman region. Contrib Mineral Petrol 90:244-257

Serri G (1990) Neogene-Quaternary magmatism of the Tyrrhenian region: characterization of the magma sources and geodynamic implications. Mem Soc Geol Ital 41:219-242

Serri G, Innocenti F, Manetti P (1993) Geochemical and petrological evidence of the subduction of delaminated Adriatic continental lithosphere in the genesis of the Neogene Quaternary magmatism of Central Italy. Tectonophysics 223:117-147

Sigurdsson IA, Kamenetsky VS, Crawford AJ, Eggins SM, Zlobin SK (1993) Primitive island arc and oceanic lavas from the Hunter ridge-Hunter fracture zone: evidence from glass, olivine and spinel compositions. Mineral Petrol 47:149-169

Sobolev AV, Sobolev NV, Smith CB, Dubessy J (1989a) Fluid and melt compositions in lamproites and kimberlites based on the study of inclusions in olivine. In: Ross $\mathrm{J}$ et al. (eds) Kimberlites and related rocks, vol 1. Geol Soc Aust Spec Publ 14, pp 220-240 4-th International Kimberlite Conference, Perth, 220-240.

Sobolev AV, Danyushevsky LV, Dmitriev LV, Suschevskaya NM (1989b) High-alumina magnesian tholeiite as the primary basalt magma at mid-ocean ridge. Geochem Int 26:128-133

Sobolev AV, Kamenetsky VS, Kononkova NN (1992) New data on Siberian meymechite petrology. Geochem Int 29:10-20

Sobolev AV, Shimizu N (1993) Ultra-depleted primary melt included in an olivine from the Mid-Atlantic Ridge. Nature 363:151-154

Sobolev AV, Nikogosian IK (1994) Petrology of long-lived mantle plume magmatism: Hawaii, Pacific and Reunion Island, Indian Ocean. Petrology 2:111-144

Sobolev AV, Shimizu N (1994) The origin of typical NMORB: the evidence from a melt inclusion study (abstract). V.M. Goldschmidt Conf. August Edinburgh, 1994, Extended Abstr, Mineral Mag 58A:829-830

Varekamp JC. (1979). Geology and petrology of the Vulsinian volcanic area (Latium, Italy). Geol Ultraiectina 22:1-384

Varekamp JC (1980) The geology of the Vulsinian area, Latium, Italy. Bull Volcanol 43:487-503

Varekamp JC (1983) The significance of mafic nodules in the ultrapotassic rocks from Central Italy - discussion. J Volcanol Geothermal Res 16:161-172

Varekamp JC, Kalamarides RI (1989) Hybridization processes in leucite tephrites from Vulsini, Italy, and the evolution of the Italian potassic suite. J Geophys Res 94:4603-4618

Watson EB (1979) Calcium content of forsterite coexisting with silicate liquid in the system $\mathrm{Na}_{2} \mathrm{O}-\mathrm{CaO}-\mathrm{MgO}-\mathrm{Al}_{2} \mathrm{O}_{3}-\mathrm{SiO}_{2}$. Am Mineral 64:824-829

Wyllie PJ, Sekine T (1982) The formation of mantle phlogopite in subduction zone hybridization. Contrib Mineral Petrol $79: 375-380$ 